\title{
Environmental initiatives: A study of dyadic buyer and supplier relationships in the South African Fast-Moving Consumer Goods industry
}

\begin{tabular}{|c|c|}
\hline \multicolumn{2}{|c|}{ 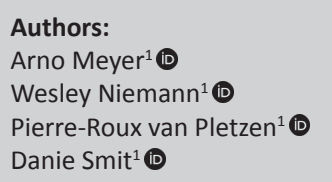 } \\
\hline \multicolumn{2}{|c|}{$\begin{array}{l}\text { Affiliations: } \\
{ }^{1} \text { Department of Business } \\
\text { Management, Faculty of } \\
\text { Economic and Manageme } \\
\text { Sciences, University of } \\
\text { Pretoria, Pretoria, } \\
\text { South Africa }\end{array}$} \\
\hline \multicolumn{2}{|c|}{$\begin{array}{l}\text { Corresponding author: } \\
\text { Arno Meyer, } \\
\text { arno.meyer@up.ac.za }\end{array}$} \\
\hline \multicolumn{2}{|c|}{$\begin{array}{l}\text { Dates: } \\
\text { Received: } 03 \text { Apr. } 2019 \\
\text { Accepted: } 30 \text { July } 2019 \\
\text { Published: } 19 \text { Sept. } 2019\end{array}$} \\
\hline \multicolumn{2}{|c|}{$\begin{array}{l}\text { How to cite this article: } \\
\text { Meyer, A., Niemann, W., } \\
\text { Van Pletzen, P.-R. \& Smit, D., } \\
\text { 2019, 'Environmental } \\
\text { initiatives: A study of dyadic } \\
\text { buyer and supplier } \\
\text { relationships in the South } \\
\text { African Fast-Moving } \\
\text { Consumer Goods industry', } \\
\text { Journal of Transport and } \\
\text { Supply Chain Management } \\
\text { 13(0), a448. https://doi.org/ } \\
\text { 10.4102/jtscm.v13i0.448 }\end{array}$} \\
\hline \multicolumn{2}{|c|}{$\begin{array}{l}\text { Copyright: } \\
\text { ๔ 2019. The Authors. } \\
\text { Licensee: AOSIS. This wor } \\
\text { is licensed under the } \\
\text { Creative Commons } \\
\text { Attribution License. }\end{array}$} \\
\hline \multicolumn{2}{|l|}{ Read online: } \\
\hline 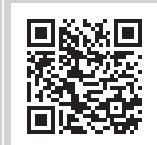 & $\begin{array}{l}\text { Scan this QR } \\
\text { code with your } \\
\text { smart phone or } \\
\text { mobile device } \\
\text { to read online. }\end{array}$ \\
\hline
\end{tabular}

Background: In the current fast-paced markets, customer demands are changing and environmental considerations have placed organisations under pressure to integrate and implement environmental initiatives in their business and supply chain functions. This pressure forces organisations to respond better to the changing global trends and customer demands.

Objectives: The purpose of this generic qualitative study was to explore environmental initiatives within the context of a dyadic buyer-supplier relationship in the South African fast-moving consumer goods (FMCG) industry.

Method: Semi-structured interviews were conducted with 12 participants. These interviews were conducted with six organisations who were engaged in a dyadic buyer-supplier relationship.

Results: The findings indicate that organisations implementing environmental initiatives experienced improved collaboration between supply chain partners. Improved collaboration leads to enhanced product quality, cost savings in the long-term and transparency between organisations. The drawbacks from environmental initiatives included increases in planning time and high capital investment. Implementing environmental initiatives revolve around buyer-supplier relationships that are strategic in nature and should not be underestimated by organisations. To improve buyer-supplier relationships, organisations are recommended to devote more capital and resources to environmental initiatives.

Conclusion: This study determined the predominant environmental initiatives within the South African FMCG context and showed how environmental initiatives influence buyer-supplier relationships.

Keywords: green supply chain management; fast-moving consumer goods; FMCG industry; dyadic relationships; environmental initiatives; qualitative research; South Africa.

\section{Introduction}

Nobel laureate Wangari Maathai stated, 'The environment and the economy are really both two sides of the same coin. If we cannot sustain the environment, we cannot sustain ourselves'. Historically, organisations primarily focused on profit without considering the impact of its activities on the environment and people on the planet (Carter \& Easton 2011:54). The changing and complex nature of customers made it imperative for organisations to incorporate environmental practices, together with their corporate governance policies, to avoid the risks of reputation-damaging events and solecisms. Dyadic relationships are derived from the field of sociology. A dyadic relationship is a group of two individuals or organisations that can be linked via common interests, relations, work and cooperation (Liden, Anand \& Vidyarthi 2016:139). Hence, the dyadic relationship for this study refers to the buyer-supplier relationship in the fastmoving consumer goods (FMCG) industry's supply chain environment.

In 2018, the Nielsen Global Responsibility Report showed that a staggering 81\% of 30000 respondents reported that organisations should actively participate in environmental initiatives to improve the environment in which they operate. However, $73 \%$ of the respondents indicated that they were willing to pay more for a product or service produced by organisations that were environmentally conscious. This shows how organisations are prepared to increase their investments into green supply chain management (GSCM) practices (Okanga \& Groenewald 2017:1696). The focus of GSCM practices is not only on the total impact of the 
organisation, but also incorporates its supplier's activities. Green supply chain management ensures sustainability, that is, in enhancing the overall performance of the supply chain (Green et al. 2012:292).

However, it may not be feasible for an organisation to implement GSCM practices without the successful collaboration of its suppliers to support any environmental initiatives. The reason is because of the large number of outsourced activities where organisations are held accountable for their own actions and the actions of the suppliers in their supply chain (Lee et al. 2014:39). However, the problem is that GSCM is not yet a mature and welldistinguished practice (Murfield \& Tate 2017:1320). For example, it is difficult to put a rand value on an oil spill, or on the prevention costs thereof. Similarly, GSCM is more than just using paper cups instead of plastic cups. This is because GSCM depends on the organisation's efforts used to achieve sustainable operations for its success (Rahim, Fernando \& Saad 2016:147). It is mainly for this reason that greater efforts are required for organisations to reduce their environmental impact or carbon footprint (Lintukangas, Hallikas \& Kähkönen 2015:321-333).

Green supply chain management has been researched in extant literature in both developed and developing countries (Jafarzadeh-Ghoushchi 2018:81). The top 10 countries in terms of GSCM research (from high to low) include the People's Republic of China, United States, Taiwan, England, India, Canada, Malaysia, Australia, Italy and Denmark. Based on this information, it clearly shows that research in developing countries, especially African countries like South Africa, is poorly represented in GSCM literature. However, GSCM received a significant amount of attention in more developed countries. The predominant studies on the drivers of and barriers to GSCM failed to address the implications of dyadic relationships during the implementation of environmental initiatives.

Extant literature indicates that to decrease the environmental effect of the supply chain, organisations need to scrutinise the source of inputs and collaborate with participating suppliers during the preliminary stages of product development (Green et al. 2012:291). The findings suggest that organisations need to shift from transactional suppliers to suppliers willing to commit themselves to long-term environmental initiatives, which is also supported by the research of Govindan et al. (2015:67). These transitions require both parties to realise how the changes will influence performance when incorporating environmental initiatives (Butner, Geuder \& Hittner 2008:10). Furthermore, Cummins (2016) indicates that up to 70\% of an organisation's carbon footprint is attributable to their upstream and downstream supply chain partners. Therefore, organisations need to consider how their buyer-supplier relationship affects the overall supply chain cost and quality performance factors (Du, Li \& Song 2016:1600).

The objectives of this qualitative study were twofold: firstly, to determine the predominant GSCM practices of buyer-supplier organisations in an African developing country such as South Africa and, secondly, to explore and focus on the dyadic buyer-supplier relationship perspectives and the implications they have on environmental initiatives. Although GSCM received a significant amount of attention, a limited number of studies address the implications of dyadic relationships during the implementation of environmental initiatives. This article also responds to the future research suggestions of Murfield and Tate (2017:1341), recommending that dyadic buyer-supplier relationships should be investigated in order to provide in-depth insights into specific supply chains and how to disseminate environmental requirements to the upstream supply chain partners to create a 'green bullwhip effect'. Similar to the concept of the bullwhip effect, Lee etal. (2014:39) suggest that'environmental requirements also change significantly at times, and are passed along the supply chain to varying degrees'.

The focus of this study is on the South African FMCG industry. The FMCG industry is one of the largest industries in the world (Mvubu \& Naude 2016:274). The FMCG industry is also characterised by its multiple supply chain partners. Suppliers typically supply low-cost non-durable products with a short shelf-lifespan (Mvubu \& Naude 2016:274). Fastmoving consumer goods products include food and beverages, dry goods, cosmetics, household cleaning products and toiletry products. Therefore, the integration of environmental initiatives into buyer-supplier relationships is noteworthy for South African FMCG organisations, as this is a fast growing industry (Rahim et al. 2016:152). According to Nielsen Connected Commerce Report (2018), global FMCG purchasing has increased by $15 \%$ in the last 2 years; however, in South Africa, FMCG purchasing has increased by $48 \%$ in the same period. To put this into perspective, South Africans spent R31 900.00 per second in FMCG stores in 2017.

The study aims to answer the following research questions:

- What are the predominant environmental initiatives within the South African FMCG industry?

- How do environmental initiatives influence buyersupplier relationships within the South African FMCG industry?

- What are the main benefits and drawbacks of environmental initiatives on dyadic buyer relationships within South Africa's FMCG industry?

The aim of this study was to provide more insights into the effects of dyadic relationships on environmental initiatives within South Africa's FMCG industry. It is imperative to determine the predominant environmental initiatives so that organisations can prioritise activities and allocate resources accordingly. It may allow FMCG organisations and practitioners to gain an in-depth understanding of the implications of dyadic supplier-buyer relationships and to exploit the advantages to avoid mistakes. These buyersupplier relationships may contribute to the various levels where an organisation may experience environmental collaboration across the organisation's network. Thus, researching and understanding the implications of dyadic 
buyer-supplier relationships may help organisations benchmark the benefits and costs, as well as encourage smaller South African organisations to participate in environmental practices.

The structure of the remainder of the article covers a comprehensive literature review pertaining to South Africa's FMCG industry, buyer-supplier relationships, GSCM and the main drivers of and barriers to GSCM. It is followed by a description of the methodology with relevant research design, sampling, data collection and analysis. Then research findings are presented. The article concludes with the theoretical implications, managerial recommendations and the limitations of the study and recommendations for future research are discussed.

\section{Literature review}

\section{The South African fast-moving consumer goods industry}

The FMCG industry is a dynamic, competitive and fast-paced industry and is described as the largest industry in the world (KPMG 2014:4). The FMCG industry predominantly consists of goods sold rapidly, consisting mainly of non-durable items consumed frequently and on a daily basis by customers (Mvubu \& Naude 2016:274). It is one of South Africa's most important prospering economic sectors for Gross Domestic Product (GDP) growth. In 2011, the FMCG industry sales surpassed a trillion rand for the first time. By 2016, this amount increased to R1.46 trillion (Statistics South Africa Report 2018). Large formal FMCG retailers account for $68 \%$ of South Africa's market and informal small, medium and micro enterprises (SMMEs), such as 'spazas', small informal superette-style shops and mid-sized wholesalers, encapsulate the rest of the market share (Dicey 2016).

Profit margins of goods and services in the FMCG industry are typically low; therefore, competitive advantage is gained by selling large volumes to FMCG retailers (Mvubu \& Naude 2016:274). Green et al. (2012:290) state that this intense competition between suppliers may also lead to suppliers being more committed to GSCM practices and initiatives set out by FMCG organisations, suggesting that the power asymmetry in this particular buyer-supplier relationship is skewed towards buyer organisations, that is, FMCG retailers. It also corroborates the findings of Sutton-Brady, Kamvounias and Taylor (2015:122), stating that the extremely condensed nature of the FMCG industry influences the buyer-supplier power imbalance.

Lacoste and Johnsen (2015:229) suggest that supplier performance in the FMCG industry is more process-driven, whereas supplier performance in other industries is more relationship-driven. However, Copeland (2013:423) suggests that strategic suppliers are often more eager to work with buyers on environmental initiatives, suggesting that buyer organisations are moving away from transactional supplier relationships and more towards strategic relationships with their key suppliers, thus focussing on environmental initiatives (Chkanikova 2016:478).

\section{Buyer-supplier relationships}

Categorising buyer-supplier relationships can be achieved by using the portfolio approach, as explained by Kraljic in the purchasing portfolio matrix (De Villiers, Nieman \& Niemann 2017:33). Kraljic highlights buyer-supplier relationships to be considered as a strategic function of an organisation. The purchasing portfolio model guides organisations to form strategic relationships with a limited number of suppliers because of limited resources (Pagell et al. 2010:58-60). Based on this logic, it is not advisable to form strategic relationships with all suppliers, as this level of commitment is too vast and costly to maintain (Cao \& Zhang 2011:164).

Kraljic's model outlines that relationships differ because of the type of purchase or categories of spend. Allocating resources appropriately enhances purchasing performance (Pagell et al. 2010:57). Kraljic's portfolio approach comes with challenging consequences when managing the environmental practices, as each situation with suppliers is unique. Both Chkanikova (2016:478-494) and Pagell et al. (2010:57-73) suggest that emphasis should be placed on environmentally aware sourcing decisions. Furthermore, companies should constantly evaluate their relationships with their suppliers and strategically consider the integration of green practices.

Another aspect of Kraljic's model is complexity management. It can be key to maintain strategic relationships. Hence, complexity managed within and between organisations plays a vital role in the relationship (Mota et al. 2015:1). When enabling factors such as trust, transfer of information and clear goals are not aligned between organisations, complexity becomes evident (Nyaga et al. 2010:104). The Kraljic model states that suppliers should focus on building trust and commitment to contribute favourably towards improved performance and buyer satisfaction for the outcomes that buyers need to value (Meyer et al. 2017:1; Nyaga et al. 2010:101). In the context of this research, the services suppliers should offer to FMCG organisations should adhere to and jointly contribute to environmental initiatives.

\section{Green supply chain management}

Green supply chain management practices are supply chain management activities that attempt to conserve the integrity of the global environment. Therefore, projects may incorporate impact reduction activities, namely: (1) recycling, material purification and low-density packaging design; (2) environmental data gathering including vendors, products as well as processes; and (3) waste elimination processes such as biodegrading and incineration (Walker et al. 2008:75). Organisations can effectively leverage internal resources to track and monitor such environmental activities across all organisational functions using green supply chain integration (GSCI) (Wong, Wong \& Boon-itt 2015:15). 
Wong et al. (2015:14-15) explain that strategic collaboration and integration across internal resources form part of GSCM. Internal resources such as senior management, quality control and organisational functions, when integrated, use an integrated management system to support organisations in managing the environmental impact of their supply chain (Wong et al. 2015:15). Increasing customer demands motivate organisations to work and pinpoint innovative environmental solutions (Green et al. 2012:292; Peuckert 2014:77-94).

Walker et al. (2008:72) indicate that organisations may encounter more barriers to the drivers of environmental supply chain projects. Knowing the causes and effects of these drivers and barriers helps to emphasise the importance of GSCM practices in all buyer-supplier relationships. The internal drivers of the organisation that focus on environmental initiatives include the personal commitment of leaders, middle management, policy entrepreneurs and stakeholders (Walker et al. 2008:69-73). These internal drivers seek to reduce costs by reducing waste and pollution often leading to production efficiencies and quality improvements.

The external drivers of an organisation usually focus on environmental initiatives such as legislation, particularly when companies are proactively innovative in their approach to regulatory compliance. External competitors also act as drivers for GSCM projects for organisations to seek competitive advantage and improved performance (Walker et al. 2008:69-73). External drivers include an increase in public awareness, consumer demand for environmentally conscious goods and processes. Additionally, the influence of non-governmental organisations (NGOs) concerned with corporate 'greenwash' is an attempt to seem interested in protecting the environment (Walker et al. 2008:80).

The barriers identified are primarily external in nature and include cultural myopia, cost implications, level of corruption, government legislation and lack of incentives, customer ignorance, lack of education or knowledge, industry-specific barriers and technology (Niemann Kotze \& Adamo 2016:977-1013). External barriers identified include lack of supply chain transparency, poor supplier commitment, lack of laws and policies and industry-specific barriers. According to Niemann et al. (2016:979-984), the barriers with the greatest effect are cultural, cost and government legislation. An organisation's internal barriers focussing on environmental initiatives usually result in cost reductions at the expense of green practices. These include lack of management commitment and lack of buyer awareness (Mittal \& Sangwan 2014:584).

\section{Methodology \\ Research design}

This study applied a generic qualitative research methodology. This type of research aligns the study to identify an exploratory basis of opinions and perspectives of managers in buyer and supplier organisations (Plano Clark
\& Creswell 2015:289). It creates an understanding of participants' opinions on a specific phenomenon (in this particular study being the dyadic buyer-supplier relationships) at a specific time (Percy, Kostere \& Kostere 2015:78). Each participant of the study was interviewed once only to define the time horizon as cross-sectional (Babbie \& Mouton 2001:93-95).

\section{Sampling}

Six dyadic relationships were investigated, consisting of 12 organisations. One participant represented each respective organisation. A purposive sampling method was used to include homogeneous and snowball sampling. The use of purposive sampling for the study allowed the researcher to select specific buyer-supplier relationships and pertinent individuals to contribute to the topic.

Generic qualitative research includes the collection of qualitative data in semi-structured interviews. The collected data are analysed and the results are used to conclude the themes identified (Kahlke 2014:40). In Table 1, all the participants involved in this study are described where ' $\mathrm{B}$ ' represents buyer organisations and ' $\mathrm{S}$ ' represents supplier organisations. The respective colours indicate the dyadic linkages. Additionally, it is important to note that the participants were not merely buyers and sellers, but middle and top management that has a more holistic and strategic point of view of the respective organisations.

\section{Data collection}

Semi-structured interviews were conducted. One of the advantages of conducting semi-structured interviews was that the researchers had more control over the information obtained (Creswell 2012:218). This provided flexibility to adapt and gather the required data (Rowley 2012:262). A discussion guide developed for the study's research questions and available extant literature underwent a pretest with a single individual. The pre-test helped the researchers to change the discussion guide to allow an easier understanding of the respective interviewees. All the interviews were audio-recorded and transcribed by the researchers within 7 days of the interview.

TABLE 1: Participant details.

\begin{tabular}{lllll}
\hline $\begin{array}{l}\text { Participant } \\
\text { number }\end{array}$ & Position & $\begin{array}{l}\text { Organisation } \\
\text { number }\end{array}$ & $\begin{array}{l}\text { Years in } \\
\text { industry }\end{array}$ & Gender \\
\hline P1 & Depot Manager & B1 & 6 & Male \\
P2 & Produce Procurement Manager & S1 & 13 & Male \\
P3 & Group Logistics Executive & B2 & 17 & Male \\
P4 & Managing Director & S2 & 13 & Female \\
P5 & Distribution Centre Manager & B3 & 8 & Male \\
P6 & Branch Manager & S3 & 19 & Male \\
P7 & National Portfolio Manager & B4 & 29 & Male \\
P8 & Commercial Executive & S4 & 25 & Male \\
P9 & Merchandise Executive & B5 & 28 & Male \\
P10 & Sustainability Manager & S5 & 20 & Male \\
P11 & Chief Executive Officer & B6 & 10 & Male \\
P12 & Account Manager & S6 & 5 & Male \\
\hline
\end{tabular}




\section{Data analysis}

Thematic analysis was used to analyse the data gathered. Thematic analysis pinpoints, examines and records the themes of the gathered data (Braun \& Clarke 2012:57). The researchers followed the guidelines of Braun and Clarke (2012:57-71) by familiarising themselves with the raw data which were examined from the audio recordings and the corresponding transcriptions. Codes were used from the literature and linked to the inductive codes, which were created from the data, to create a code list. Similar codes were grouped together to identify sub-themes. The researchers were all involved in the coding and analysis of the raw data. Researchers actively reviewed the perspectives and findings of the other researchers. This was done to increase the study's trustworthiness and to decrease biased perspectives of any one researcher.

\section{Trustworthiness}

The criteria to ensure the trustworthiness of the study include credibility, dependability, confirmability and transferability (Polit \& Beck 2012:584; Shenton 2004:64). Credibility entails that the findings of the study offer an accurate reflection of the state of the phenomenon in reality (Polit \& Beck 2012:585). Voluntary participation and the confidentiality of participants guaranteed the use of reliable methods such as purposive sampling and thematic analysis (Polit \& Beck 2012:584-585; Shenton 2004:64-69). Dependability was used to ensure that the findings were consistent and similar when the same context, participants and methods involved are in a replicated study (Polit \& Beck 2012:585; Shenton 2004:71). The researchers ensured an in-depth and detailed description of the participants, context and methodology provided to create a well-defined path for future attempts to replicate the study.

Confirmability was used for the objectivity of the findings and the fact that they are not influenced by the researcher's own ideals or frame of reference (Shenton 2004:64). To help improve confirmability, the researchers used clear audit trails that would ensure that the findings are a true reflection of the participants' opinions. Transferability was also used for another setting or context (Polit \& Beck 2012:585; Shenton 2004:67-71). A comprehensive explanation of the context of the qualitative study, as well as the discussion guide and interview protocol of the study, is provided.

\section{Ethical considerations}

The relevant Research Ethics Committee at the University of Pretoria approved the study. Each participant signed a consent form, giving voluntary consent for the interview. The researchers emphasised that the information gathered during the interviews will be treated as anonymous and confidential. To ensure that the participants were comfortable before and during the interview, the researchers reminded the participants that they might withdraw from answering a question.

\section{Findings}

This section provides findings of the four themes identified and extracted from the collected data. The following themes were identified: (1) influence of environmental initiatives upon buyer-supplier relationships, (2) issues influencing buyer and supplier management, (3) predominant environmental initiatives and (4) effects of environmental initiatives on dyadic relationships. The related sub-themes are discussed under each main theme.

\section{Predominant environmental initiatives from a South African perspective}

The first research question identifies the predominant environmental initiatives within the South African FMCG industry. Table 2 summarises the predominant environmental initiatives discussed by participants.

Five participants discussed the reduction in plastics as a popular topic amongst buyer and supplier companies. The approach of correctly managing plastics through recycling or incineration varied between supplier and buyer companies, which are evident in the following quotes:

'I think currently it is a plastic issue. If you look at the media on environmental issues it is dominated by plastic issues, because it is on a high level. It is dominant through managers and everyone who is commenting on it, saying 'Listen guys, we need to change this, it is becoming a huge problem in the total environment'. This plastic issue has been a very dominant or prominent issue on the table.' (P8, male, Commercial Executive)

'[a]nd then with that is reduction of plastics. So, if you are going to produce something at the moment using plastic, everybody wants to get rid of it.' (P1, male, Produce Procurement Manager)

'Plastic is the only thing that may not be sure where it fits, but it is something that is becoming a very environmental issue. The whole use of plastic is an issue that is driven by consumers and has become very pertinent in pollution of the oceans and the fact that many of the plastics used are not biodegradable.' (P8, male, Commercial Executive)

Three participants mentioned that the carbon footprint needs to be a predominant environmental initiative. Global warming has been a major topic over the last decade with greenhouse gasses and emissions stemming from $\mathrm{CO}_{2}$

TABLE 2: Predominant environmental initiatives identified by respondents.

\begin{tabular}{|c|c|c|c|c|c|c|c|c|c|c|c|c|c|}
\hline Sub-themes & P1 & P2 & P3 & P4 & P5 & P6 & P7 & P8 & P9 & P10 & P11 & P12 & Total \\
\hline Plastic reduction & $x$ & - & - & $x$ & - & - & $x$ & $x$ & $x$ & - & - & - & 5 \\
\hline Carbon footprint & - & - & - & - & $x$ & - & - & - & - & $x$ & - & $x$ & 3 \\
\hline Waste management & - & $x$ & $x$ & - & - & - & - & - & - & - & - & - & 2 \\
\hline Water usage & - & - & - & - & - & $x$ & - & - & - & - & $\mathrm{x}$ & - & 2 \\
\hline
\end{tabular}

P, participant. 
released by transportation and industry. Prior research conducted by Sundarakani et al. (2010:43) recommends that a significant effort needs to be made within organisations to reduce their carbon footprint. Refer to the exemplary quotes:

'The fumes are the most important thing that we must look at, because we really need to be responsible in the way that we protect our ozone layer.' (P12, male, Account Manager)

'I think it is just where the issues involving the environment are currently, like burning a lot of coal in your boilers or driving a lot of products around.' (P8, male, Commercial Executive)

Waste management refers to recycling, cutting down on noneco-friendly products and the correct disposal of materials regarded as waste (Walker et al. 2008:75). The participants regarded waste management as the predominant environmental initiative because they explained that it has a significant impact on the environment, as shown in the following quotes:

'Where we basically can make a big difference is waste management, utilisation of vehicles, reduction of trips, less vehicles on the road, less diesel and carbon footprint improvement.' (P2, male, Depot Manager)

'Anything that has a direct influence on the sustainability of our environment, be it source material, be it the relationship with various parties that actually provide that stuff to you. Also the safe disposal thereof afterwards starts impacting the environment.' (P3, male, Group Logistics Executive)

Two participants emphasised the importance of water management with regard to recycling. In South Africa, a country plagued with low levels of annual rain, the need for environmental initiatives is a major priority, as clear in the following quotes:

'Our water and contamination of water is without doubt our biggest problem for our country. We are not an agriculture rich country. Go and have a look at the average rainfalls rate. To think that we are taking it and contaminating it.' (P11, male, CEO)

'The Cape Town suppliers actually said to us that due to the environmental programme, they were already on a water saving scheme. So they were already geared up for this drought. There was no real shortage from our local farmers, because they were already using that minimal amount of water due to practices that were installed.' (P1, male, Produce Procurement Manager)

These findings are consistent with the extant literature on the benefits and performance impacts of environmental initiatives (Corbett \& Klassen 2006; Murfield \& Tate 2017; Walker et al. 2008).

\section{Influence of environmental initiatives on buyer-supplier relationships}

In the initial stages of adopting the environmental initiatives, the conflict between the buyer and supplier organisations was evident. As relationships grew stronger, collaboration, trust and alignment reduced conflict, which is evident in the following quotes:

'I mean once we have understood what they can do and once they understand what we can do, we obviously went through stages where you have to understand each other. There might be conflict or there might be disagreement, but that is part of it. You work through it. If you believe in the end goal where you want to be, then you work through those things to get to the end goal.' (P3, male, Group Logistics Executive)

'So if you look at the changes there was a little bit of negativity in the beginning. I was not there, but I heard that it was a bit tough in the beginning, but at the moment it is amazingly positive.' (P1, male, Produce Procurement Manager)

Nyaga et al. (2010:101-114) demonstrate the benefits within relationships such as information sharing, joint relationship endeavours and investments that lead to trust and commitment. In the process, trust and commitment lead to an increased level of satisfaction and performance, as shown in the following quotes:

'Trustworthy suppliers are quite important and from my experience it's very important for us to share some of the vision, you know, similar goals for that matter.' (P5, male, DC Advanced Manager)

'This is the only way you are going to get to different solutions: if you work together.' (P3, male, Group Logistics Executive)

Previous research suggests that transparency leads to improved performance between organisations and the findings of this study correlate with the extant literature. Suppliers often find themselves in a competitive environment leading to suppliers being more committed to environmental initiatives ultimately increasing the collaboration efforts between buyer and supplier organisations (Green et al. 2012:290). This is clear in the following quotes:

'I think it is more forced on us by market conditions than for anything else, so we are always in a cost improvement state of mind and that we stay competitive in the market.' (P8, male, Commercial Executive)

The findings of this study highlight that environmental initiatives have become part of the organisation's culture, thus improving the organisation's relationships and ultimately making them more strategic, as shown in the below quotes:

'Obviously it's not only positive, but also the right thing to do ...' (P1, male, Produce Procurement Manager)

'... it all stems from your sustainability policy that is integrated into company DNA and that strategy gets revised on an annual basis ...' (P10, male, Sustainability Manager)

In addition, the findings suggest that the importance of strategic sourcing impacts buyer-supplier relationships when implementing environmental initiatives. This links with the research of Chkanikova (2016:478-494) and Pagell et al. (2010:57-73), emphasising environmental awareness of source decisions. This is clear in the following quotes:

'Absolutely, again we don't see it as environmental initiative, but if we are able to make a choice between two identical products where the commercial production is pretty similar, but there is that initiative that one of those suppliers have a positive impact on the environment, it will impact the purchasing decision.' (P9, male, Merchandise Executive) 
Interestingly, the research found that suppliers use similar criteria when choosing to do business with buyers:

'We are trying to ensure that we are moving in a direction where we are only supplying organisations that are in line with our future strategy and future growth. In order for us to do that, we need to have a strategy from our side, saying that the kind of products which we are promoting or marketing are in line with environmental effectiveness. It would vertically affect the supplying strategy.' (P12, male, Account Manager)

Butner et al. (2008:10) state that organisations in a buyersupplier relationship consider how performance is affected when incorporating cost, quality and service with environmental standards. This study found that the cost, quality and service considered by organisations when balancing performance measures with environmental requirements are consistent with the findings of Butner et al. (2008:10). This is shown in the below quotes:

'Certain products across the country and making sure that our supply chain is as optimal as possible regarding environmental issues. So you know at the end of the day that all of these environmental factors are sort of bestowed or captured into the products.' (P8, male, Commercial Executive)

'Thirdly, what is the impact of the environmental decision on the overall cost of that product?' (P3, male, Group Logistics Executive)

\section{Issues influencing buyer and supplier management and development pertaining to environmental initiatives}

The second research question of the study focuses on the main issues facing an organisation implementing environmental initiatives. Table 3 provides a brief overview of the issues experienced by participants of organisations, clearly indicating the cost as a predominant factor when implementing environmental initiatives.

An organisation's level of investment and the cost implications of environmental initiatives were identified as key influencers of GSCM. The challenges identified by Niemann et al. (2016:977-1013) included cost implication and lack of knowledge. The study also explained that one of the challenges is cost, as mentioned by one respondent:

'I need to understand your current business standing, and when it comes to cost, I mean anything according to my experience, anything that leads to environmental effectiveness leads to using more money. Environmental initiatives have a high cost factor. You need to ensure that whatever it is you need to do, you need to make sure that it aligns with the current capabilities of an organisation because the costs are very high.' (P12, male, Account Manager)
Rahim et al. (2016:147) point out that an organisation's success lies in its efforts to achieve sustainable operations. To address this challenge, organisations have realised the need for sustainable practices and the reduction of their environmental impact. Organisations need to invest greater efforts toward sustainable practices. This study also found sustainability to be a factor when implementing environmental initiatives, as expressed by the following quote:

'Sustaining product quality and ensuring the way it is produced, leads to environmental effectiveness.' (P12, male, Account Manager)

This study identified the experience of organisations relating to the issues of commitment regarding environmental initiatives. Some participants mentioned this as one of the first issues experienced when implementing environmental initiatives:

'You've got to get buy in first. I had to get buy in from the marketing department and the Board to make sure that they are happy with the fact that I am continuing the process ...' (P7, male, National Portfolio Manager)

When investigating the challenges regarding environmental impact, qualitative data gathered identify practicality as an issue, which was not found in previous studies. Buyer and supplier organisations may be capable of pursuing specific environmental initiatives. However, the low level of practicality-specific environmental initiatives is avoided, as stated in the following quote:

'Can it be done, does it make sense, is there benefit, is it sustainable?' (P3, male, Group Logistics Executive)

\section{Effects of environmental initiatives upon dyadic relationships}

The final research question aimed to identify the benefits and drawbacks of environmental initiatives on buyer-supplier relationships. Peuckert (2014:77-94) and Green et al. (2012:292) point out that the competitive market drives suppliers to become more motivated to work with buyers, to pinpoint innovative environmental solutions. The findings of the current study confirm that organisations are collaborating to identify the best environmental initiatives, to help them sustain a competitive position in the market, which is evident in the following quote:

‘[B]y working together we are forming strategic directions and initiatives. This means that we work on their position in the market, and their strengthening in the market consequently this leads to growth and sustainability.' (P12, male, Account Manager)

Production efficiencies and quality improvements are the result of internal drivers aiming to minimise cost by reducing

TABLE 3: Overview of participants' responses.

\begin{tabular}{|c|c|c|c|c|c|c|c|c|c|c|c|c|c|}
\hline Sub-themes & P1 & P2 & P3 & P4 & P5 & P6 & P7 & P8 & P9 & P10 & P11 & P12 & Total \\
\hline Cost implications & $x$ & $x$ & - & $x$ & - & - & $x$ & $x$ & $x$ & $x$ & $x$ & $x$ & 9 \\
\hline Commitment & $x$ & - & $x$ & $x$ & - & - & $x$ & - & - & $x$ & - & $x$ & 6 \\
\hline Sustainability & - & - & $x$ & $x$ & $x$ & $x$ & - & - & - & - & - & - & 4 \\
\hline Practicality & - & - & $x$ & - & - & - & - & - & - & - & - & - & 1 \\
\hline
\end{tabular}

P, participant. 
waste and pollution (Walker et al. 2008:69-73). The findings of this study confirm that cost is reduced by reducing waste products, ultimately leading to the improvement of product quality, as clear from the below quotes:

'At the moment it is amazingly positive, due to the fact that they are actually now saving money, because they are using a lot less water, a lot less pesticide and herbicide, a lot less of all of those products.' (P1, male, Produce Procurement Manager)

'So there is a positive side to doing this. It is not all negative and costly. You get a benefit and you get a reward for it afterwards, because of the effect it has on your product quality, and you also do it with a responsible supplier.' (P11, male, Account Manager)

Lastly, this research identified organisations experiencing longer planning times with regard to the environmental initiatives. This aspect was not identified in the literature review and it adds to the contributions of this study, as referred to in the following quotes:

'It is getting people involved and it takes time.' (P4, female, Managing Director)

'Look, you have to be more patient and you have to put a lot more people in place to follow-up.' (P2, male, Depot Manager)

\section{Conclusion \\ Summary of findings}

This research sought to determine the predominant environmental initiatives between buyer and supplier organisations and investigated the benefits and drawbacks of environmental initiatives upon dyadic relationships. It was found that when implementing environmental initiatives, buyer-supplier relationships undergo friction. In the longterm, benefits justify the investment required when building strong relationships. In South Africa's FMCG industry, buyer organisations included environmental initiatives as a key requirement in their supplier selection criteria.

Buyer and supplier relationships are built on high standards of quality and trust. They include providing high-quality goods and services, to be sustainable over the long-term. This study confirms that similar requirements were implemented both on the buyer's and the supplier's side. When investigating an organisation's level of investment into green initiatives, the phrase 'going green costs a lot of green' is relevant to both buyer and supplier organisations. Investment includes the need for capital, skilled resources, research and development, labour requirements and training. These challenges may discourage buyer and supplier firms when developing and managing environmental initiatives.

In addition, the challenge of managing the organisation's environmental impact involves two key elements, namely practicality and sustainability. When implementing environmental initiatives, both buyer and supplier organisations expressed concern regarding the risk involved, the level of commitment and investment required for specific environmental initiatives. This means that collaboration between the buyer and supplier needs to create a win-win situation. If this is not created, the environmental initiative will not be sustainable in the long run. The collected data suggested that both buyer and supplier organisations are aware of the environmental impact on the management of plastic, water and other waste. Buyers and suppliers need to become more susceptible to the use of supplementary products, in order to reduce the overall environmental impact of the organisation.

Benefits exist for both the buyer and supplier where collaboration is evident. The key lies in the strategic alignment of supply chains sharing information and resources proven to yield short-term and long-term benefits. The potential benefits include cost saving, improved quality and improved sales. The study found that long-term benefits are from strong buyer and supplier relationships earning trust. A high level of trust between the buyer and supplier proved to be a success factor when implementing environmental initiatives. The study also highlighted potential drawbacks to implementing environmental initiatives. It found that organisations do not feel the need to invest or procure substitute products when plastics are cheaper than alternative biodegradable solutions. A second drawback was an increase in planning time and time required to implement environmental initiatives. Although the South African FMCG market is highly competitive, not all organisations are willing to invest the time and money required to implement sustainable environmental solutions.

\section{Theoretical implications}

Firstly, the literature review identified that the buyer-supplier relationship becomes strategic when implementing environmental initiatives. Buyer organisations also integrate environmental initiatives into their supplier selection criteria. The research confirms the extant literature from a South African FMCG industry context. Secondly, the literature reviewed recognised issues on the implementation of environmental initiatives, namely cost implications, lack of knowledge and labour requirements. The findings indicate that these issues were consistent with the previous research findings. This study further contributed by investigating the predominant environmental initiatives from a South African FMCG industry context. The findings identified four environmental initiatives: waste management, plastic reduction, water recycling and carbon footprint. Lastly, the findings identified the implications of environmental initiatives on buyer-supplier relationships. Benefits included competitiveness, cost saving and improved product quality. Drawbacks included longer planning times and cost implications of implementation. The current study's findings corroborate the implications found in a previous investigation by Murfield and Tate (2017:1319-1350).

\section{Managerial recommendations}

This study has several implications for managers in buying and supplying organisations. Firstly, the findings regarding the implementation of environmental initiatives suggest that buyer and supplier organisations should increase their 
operational transparency before implementing environmental initiatives, to manage challenges. Both organisations need to understand the processes and objectives of all the parties involved. Secondly, suppliers need to be aware that implementing environmental initiatives with their customers could potentially strengthen their competitive position in the market. Therefore, buyer organisations should ensure their environmental strategies aligned with those of their suppliers, as buyer organisations are liable for the acts of their suppliers. Finally, it is difficult to manage the implementation of environmental initiatives, as both organisations need to collaborate and develop a measurement system specifically related to environmental initiatives. This will ensure effective management. Several organisations have already implemented measurements such as water usage, emissions and waste into their scorecards. These measurements serve as differentiators or order qualifiers.

\section{Limitations and directions for future research}

There are several limitations of this study. Firstly, a crosssectional time horizon only provides a snapshot of reality (Babbie \& Mouton 2001:93-95). This is information gathered at one point in time between buyer and supplier organisations. It would be beneficial if a similar study is conducted, using a longitudinal time horizon, as it would provide more insights into how the relationships evolve over a long period. Next, this study was conducted within the FMCG industry, which is seen as a very broad spectrum. Future research should focus on other industries in South Africa in order to identify whether the general findings of this study are consistent across different industries. Lastly, participants may be hesitant to share negative experiences, especially if the experiences are sensitive in nature, when interviewing participants. Quantitative research, namely the use of surveys, specifically the anonymity thereof, could encourage participants to be more open when disclosing negative experiences.

\section{Acknowledgements Competing interests}

The authors declare that they have no financial or personal relationship(s) that may have inappropriately influenced them in writing this article.

\section{Authors' contributions}

P.V.P. and D.S. collected data for the research as part of their honours degree. A.M. and W.N. acted as the supervisors of the research and prepared the manuscript.

\section{Funding information}

The authors declare that they have no financial or personal relationships that may have inappropriately influenced them in writing this article.

\section{Data availability statement}

The data is stored in accordance with institutional policy.

\section{Disclaimer}

The views and opinions expressed in this article are those of the authors and do not necessarily reflect the official policy or position of any affiliated agency of the authors.

\section{References}

Babbie, E. \& Mouton, J., 2001, The practice of social research, South African edn., Oxford University Press, Cape Town.

Braun, V. \& Clarke, V., 2012, 'Thematic analysis', in H. Cooper (ed.), APA handbook of research methods in psychology, American Psychological Association, Washington DC, WA.

Butner, K., Geuder, D. \& Hittner, J., 2008, Mastering carbon management: Balancing trade-offs to optimize supply chain efficiencies, viewed 04 March 2019, from www.05.ibm.com/de/automative/donwloads/mastering-carbon-management.pdf.

Cao, M. \& Zhang, Q., 2011, 'Supply chain collaboration: Impact on collaborative advantage and form performance', Journal of Operations Management 29, 163-180. https:// doi.org/10.1016/j.jom.2010.12.008

Carter, C.R. \& Easton, P.L., 2011, 'Sustainable supply chain management: Evolution and future directions', International Journal of Physical Distribution \& Logistics Management 41(1), 46-59. https://doi.org/10.1108/09600031111101420

Chkanikova, O., 2016, 'Sustainable purchasing in food retailing: Interorganizational relationship management to green product supply', Business Strategy and the Environment 25(7), 478-494. https://doi.org/10.1002/bse.1877

Copeland, B.R., 2013, 'Trade and the environment', Palgrave handbook of international trade, pp. 423-496, Palgrave Macmillan, London.

Corbett, C.J. \& Klassen, R.D., 2006, 'Extending the horizons: Environmental excellence as key to improving operations', Manufacturing \& Service Operations Management 8(1), 5-22. https://doi.org/10.1287/msom.1060.0095

Creswell, J.W., 2012, Educational research: Planning, conducting, and evaluating quantitative and qualitative research, 4th edn., Pearson, Boston, MA

Cummins, C., 2016, You, too, can master supply chain emissions, viewed 11 January 2019, from www.greenbiz.com/article/youtoocanmastersupplychainemissions.

De Villiers, G., Nieman, G. \& Niemann, W., 2017, Strategic logistics management: A supply chain management approach, 2nd edn., Van Schaik Publishers, Pretoria, South Africa.

Dicey., 2016, FMCG insights into a changing retail scene, viewed 05 March 2019, from https://www.businesslive.co.za/redzone/news-insights/2016-05-11-fmcginsights-into-a-changing-retail-scene/.

Du, S., Li, H. \& Song, M., 2016, 'Production optimization considering environmental performance and preference to the cap-and-trade system', Journal of Cleaner Production 112, 1600-1607. https://doi.org/10.1016/j.jclepro.2014.08.086

Govindan, K., Rajendran, S., Sarkis, J. \& Murugesan, P., 2015, 'Multi criteria desicion making approachesfor green supplier evaluation and selection: A literature review', Journal of Cleaner Production 98, 66-83. https://doi.org/10.1016/j. jclepro.2013.06.046

Green Jr, K.W., Zelbst, P.J., Meacham, J. \& Bhadauria, V.S., 2012, ‘Green supply chain management practices: Impact on performance', Supply Chain Management: An International Journal 17(3), 290-305. https://doi.org/10.1108/135985412112 27126

Jafarzadeh-Ghoushchi, S., 2018, 'Qualitative and quantitative analysis of Green Supply Chain Management (GSCM) literature from 2000 to 2015', International Journal of Supply Chain Management 7(1), 77-86.

Kahlke, R.M., 2014, 'Generic qualitative approaches: Pitfalls and benefits of methodological mixology', International Journal of Qualitative Methods 13, 37-52. https://doi.org/10.1177/160940691401300119

KPMG, 2014, Fast moving consumer goods in Africa, viewed 15 February 2019, from https://kpmg.com/Africa.

Lacoste, S. \& Johnsen, R.E., 2015, 'Supplier-customer relationships: A case study of power dynamics', Journal of Purchasing and Supply Management 21(4), 229-240. https://doi.org/10.1016/j.pursup.2014.12.006

Lee, S.Y., 2008, 'Drivers for the participation of small and medium-sized suppliers in green supply chain initiatives', Supply Chain Management: An International Journal 13(3), 185-198. https://doi.org/10.1108/13598540810871235

Liden, R.C., Anand, S. \& Vidyarthi, P., 2016, 'Dyadic relationships', Annual Review of Organizational Psychology and Organizational Behavior 3, 139-166. https://doi. org/10.1146/annurev-orgpsych-041015-062452

Lintukangas, K., Hallikas, J. \& Kähkönen, A.K., 2015, 'The role of green supply management in the development of sustainable supply chain', Corporate Social Responsibility and Environmental Management 22(6), 321-333. https://doi. org/10.1002/csr.1348

Meyer, A., Niemann, W. \& Kotzé, T., 2017, 'Exploring the dark side of interpersonal relationships between buyers and suppliers of logistics services', Acta Commerci 17(1), 1-12. https://doi.org/10.4102/ac.v17i1.437

Mittal, V.K. \& Sangwan, K.S., 2014, 'Development of a model of barriers to environmentally conscious manufacturing implementation', International Journal of Production Research 52(2), 584-594. https://doi.org/10.1080/00207543.2013. 838649

Mota, B., Gomes, M.I., Carvalho, A. \& Barbosa-Povoa, A.P., 2015, 'Towards supply chain sustainability: Economic, environmental and social design and planning', Journal of Cleaner Production 105, 14-27. https://doi.org/10.1016/j.jclepro.2014.07.052 
Murfield, M.L. \& Tate, W.L., 2017, 'Buyer and supplier perspectives on environmental initiatives: Potential implications for supply chain relationships', The International
Journal of Logistics Management 28(4), 1319-1350. https://doi.org/10.1108/ Journal of Logistics
IJLM-06-2016-0138

Mvubu, M. \& Naude, M.J., 2016, 'Green supply chain management constraints in the South African fast-moving consumer goods industry: A case study', Journal of Contemporary Management 13(1), 271-297.

Nielsen, 2018, Nielsen Global Responsibility Report, viewed 12 January 2019, from https://www.nielsen.com/us/en/insights/article/2018/was-2018-the-year-ofthe-influential-sustainable-consumer/.

Niemann, W., Kotze, T. \& Adamo, F., 2016, 'Drivers and barriers of green supply chain management implementation in the Mozambican manufacturing industry', Journal of Contemporary Management 13(1), 977-1013.

Nyaga, G.N., Lynch, D.F. \& Whipple, J.M., 2010, ‘Examining supply chain relationships: Do buyer and supplier perspectives on collaborative relationships differ?', Journal of Operations Management 28(2), 101-114. https://doi.org/10.1016/j.jom.2009.07.005

Okanga, B. \& Groenewald, D., 2017, 'Leveraging effects of triple bottom lines business model on the building and construction small and medium-sized enterprises' market performance', Acta Commercii 17(1), 1684-1999. https://doi.org/10.4102/ ac.v17i1.457

Pagell, M., Wu, Z. \& Wasserman, M.E., 2010, 'Thinking differently about purchasing portfolios: An assessment of sustainable sourcing', Journal of Supply Chain Management 46(1), 57-73. https://doi.org/10.1111/j.1745-493X.2009.03186

Percy, W.H., Kostere, K. \& Kostere, S., 2015, 'Generic qualitative research in psychology', Qualitative Report 20(2), 76-85, viewed 01 December 2018, from http://www.nova.edu/ssss/QR/QR20/2/percy5.pdf

Peuckert, J., 2014, 'What shapes the impact on environmental regulation on competitiveness? Evidence from executive opinion surveys' Environmental Innovation and Societal Transitions 10, 77-94. https://doi.org/10.1016/j.eist.2013.09.009
Plano Clark, V.L. \& Creswell, J.W., 2015, Understanding research: A consumer's guide, 2nd edn., Pearson Education, Inc., Boston, MA.

Polit, D.F. \& Beck, C.T., 2012, Nursing research: Generating and assessing evidence for nursing practice, 9th edn., Lippincott Williams \& Wilkins, Philadelphia, PA.

Rahim, S.A., Fernando, Y. \& Saad, R., 2016, 'Sustainable green supply chain management and impact on organisations', Journal of Emerging Trends in Economics and Management Sciences (JETEMS) 7(3), 147-155.

Rowley, J., 2012, 'Conducting research interviews', Management Research Review 35(3), 260-271. https://doi.org/10.1108/01409171211210154

Shenton, A.K., 2004, 'Strategies for ensuring trustworthiness in qualitative research projects', Education for Information 22(2), 63-75. https://doi.org/10.3233/EFI2004-22201

Statistics South Africa Annual Report, 2018, viewed 01 December 2018, from http:// www.statssa.gov.za/publications/AnnualReport/Annual_report_2017_18 Book_1.pdf.

Sundarakani, B., De Souza, R., Goh, M., Wagner, S.M. \& Manikandan, S., 2010 'Modeling carbon footprints across the supply chain', International Journal of Production Economics 128, 43-50. https://doi.org/10.1016/j.ijpe.2010.01.018

Sutton-Brady, C., Kamvounias, P. \& Taylor, T., 2015, 'A model of supplier-retailer power asymmetry in the Australian retail industry', Industrial Marketing Management 51, 122-130. https://doi.org/10.1016/j.indmarman.2015.05.008

Walker, H., Di Sisto, L. \& Mcbain, D., 2008, 'Drivers and barriers to environmental supply chain management practices: Lessons from the public and private sectors', Journal of Purchasing \& Supply Management 14(1), 69-85. https://doi. org/10.1016/j.pursup.2008.01.007

Wong, C., Wong, C.W. \& Boon-itt, S., 2015, 'Integrating environmental management into supply chain: A systematic literature review and theoretical framework', International Journal of Physical Distribution \& Logistics Management 45(1), 43-68. https://doi.org/10.1108/IJPDLM-05-2013-0110 